\title{
Anaerobic pathways of glycerol dissimilation by Enterobacter agglomerans CNCM 1210: limitations and regulations
}

\author{
Fabien Barbirato, ${ }^{1}$ Suzette Astruc, ${ }^{1}$ Philippe Soucaille, ${ }^{2}$ Carole Camarasa, ${ }^{3}$ \\ Jean Michel Salmon ${ }^{3}$ and André Bories ${ }^{1}$
}

Author for correspondence: André Bories. Tel: +334684944 06. Fax: +33468494402.

1 INRA, Laboratoire de Microbiologic Industrielle et Génétique des Microorganismes, 11430 Gruissan, France

2 INSA, Centre de Bioingénierie Gilbert Durand, Complexe Scientifique de Rangueil, 31077 Toulouse, France

3 INRA, IPV, Laboratoire de Microbiologie et Technologie des Fermentations, 2 Place Viala, 34060 Montpellier Cedex 01, France

\begin{abstract}
Continuous cultures of Enterobacter agglomerans CNCM 1210 were performed under regulated pH conditions (pH 7.0) with glycerol or glucose $\left(20 \mathrm{~g} \mathrm{l}^{-1}\right)$ as carbon source. Cultures grown on glucose produced mainly acetate, ethanol and formate. In contrast, 1,3-propanediol (PPD) was the main product with glycerol. The carbon flow distribution at branching metabolic points was investigated. Higher PPD yields with increased dilution rate were correlated with an important increase in the relative ratio of glycerol dehydratase to glycerol dehydrogenase. Determination of intracellular triose-phosphate and fructose 1,6-biphosphate concentrations demonstrated that glyceraldehyde-3phosphate dehydrogenase is the limiting step in glycerol dissimilation. At the pyruvate branching point, pyruvate dehydrogenase (PDH) activity was systematically detected. The pyruvate flow shifted to PDH is suspected to represent up to $22 \%$ of the acetyl-CoA formed. In addition, this enzyme pattern combined with the enhanced in vivo lactate dehydrogenase activity at high growth rates, was correlated with a decrease in the pyruvate formatelyase activity. A regulation of this latter enzyme by the accumulation of triosephosphate is suspected.
\end{abstract}

Keywords: Enterobacter agglomerans, glycerol, carbon flow distribution and regulation, reducing equivalent flow, 1,3-propanediol

\section{INTRODUCTION}

Due to the scheduled expansion of vegetable oil processing activities (biodiesel), abundant glycerol sources are expected to be generated (Eggersdorfer et al., 1992; Chowdhury \& Fouhy, 1993). For this reason, microbial conversion of glycerol to various compounds has been investigated recently and particularly focused upon 1,3propanediol (PPD) production (Günzel et al., 1991; Biebl et al., 1992; Petitdemange et al., 1995). This hallmark product is of interest in the synthesis of polyesters because of the outstanding properties it confers to the material in terms of mechanical resistance (Elm et al., 1980) and biodegradability (Witt et al., 1994).

Abbreviations: $A D H$, alcohol dehydrogenase; $D A$, dehydratase; $D H$, dehydrogenase; DHA, dihydroxyacetone; DHAP, dihydroxyacetone phosphate; FBP, fructose 1,6-biphosphate; G3P, glycerol 3-phosphate; GAP, glyceraldehyde 3-phosphate; 3-HPA, 3-hydroxypropionaldehyde; KPB, potassium phosphate buffer; $L D H$, lactate dehydrogenase; $P D H$, pyruvate dehydrogenase; PFL, pyruvate formate-lyase; PPD, 1,3-propanediol.
The fermentation of glycerol to PPD has been mainly studied with micro-organisms such as Klebsiella pneumoniae (Ogbe Solomon et al., 1994; Zeng et al., 1993; Streekstra et al., 1987), Citrobacter freundii (Homann et al., 1990; Boenigk et al., 1993) and Clostridium butyricum (Abbad-Andaloussi et al., 1996; Saint Amans, 1994; Forsberg, 1987). Enterobacter agglomerans is able to convert glycerol to PPD as the major product and to acetic, formic, lactic and succinic acids and ethanol as by-products (Barbirato et al., 1995). The metabolic flexibility of this strain was demonstrated by varying the initial glycerol content during batch fermentation regulated at $\mathrm{pH} 7$ : the higher the initial substrate concentration, the higher the PPD conversion yield. However, increasing glycerol content, and thus glycerol uptake rate, resulted in the accumulation of an intermediate metabolite. Identified as 3hydroxypropionaldehyde (3-HPA), it caused cessation of both growth and product formation (Barbirato et al., 1996a, b).

In the present study, we investigated the metabolic 
behaviour of E. agglomerans growing anaerobically in a continuous culture with glycerol or glucose as sole carbon source. On the one hand, this was accomplished by following the carbon flow distribution at several important branching points, as well as the regeneration of reducing equivalents. On the other hand, the activities of key enzymes involved in the dissimilation of glycerol and nucleotide pools were measured. Effects of a high specific rate of glycerol dissimilation on the metabolic pathway used are discussed.

\section{METHODS}

Bacterial strain and growth conditions. The bacterial strain Enterobacter agglomerans CNCM 1210 (Collection Nationale de Cultures de Microorganismmes, Institut Pasteur, Paris, France) was grown in carbon-source-limited, anaerobic continuous cultures. Feed medium contained (per litre deionized water) : $20 \mathrm{~g}$ glycerol or glucose as carbon source, $1 \mathrm{~g} \mathrm{~K}_{2} \mathrm{HPO}_{4}$, $0.5 \mathrm{~g} \mathrm{KH}_{2} \mathrm{PO}_{4}, \quad 2 \mathrm{~g}\left(\mathrm{NH}_{4}\right)_{2} \mathrm{SO}_{4}, 0.4 \mathrm{~g} \mathrm{MgSO}_{4} .7 \mathrm{H}_{2} \mathrm{O}, 0.1 \mathrm{~g}$ $\mathrm{CaCl}_{2} \cdot 2 \mathrm{H}_{2} \mathrm{O}, 4 \mathrm{mg} \mathrm{CoCl} 2,2 \mathrm{~g}$ yeast extract (Biokar diagnostic), $0.5 \mathrm{~g}$ bactopeptone (Difco), $0.3 \mathrm{~g}$ bacteriological meat extract (Biokar) and $1 \mathrm{ml}$ of a mineral solution containing (per litre deionized water): $5 \mathrm{~g}$ EDTA, $2 \mathrm{~g} \mathrm{FeSO}_{4} \cdot 7 \mathrm{H}_{2} \mathrm{O}, 1 \mathrm{~g}$ $\mathrm{MnCl}_{2} .4 \mathrm{H}_{2} \mathrm{O}, 0.2 \mathrm{~g} \mathrm{CuCl}_{2} .2 \mathrm{H}_{2} \mathrm{O}, 0.2 \mathrm{~g} \mathrm{H}_{3} \mathrm{BO}_{3}, 30 \mathrm{mg}$ $\mathrm{Na}_{2} \mathrm{MoO}_{4} \cdot 2 \mathrm{H}_{2} \mathrm{O}, \quad 30 \mathrm{mg} \mathrm{NiCl} \cdot 2 \mathrm{H}_{2} \mathrm{O}$ and $0 \cdot 1 \mathrm{~g}$ $\mathrm{ZnSO}_{4} .7 \mathrm{H}_{2} \mathrm{O}$. Bottles (10 or 20 litres) containing the feed medium were degassed for $20-24 \mathrm{~h}$ under a sterile nitrogen flux after being autoclaved $\left(30 \mathrm{~min}\right.$ at $\left.120^{\circ} \mathrm{C}\right)$. Experiments were carried out in 1 litre glass reactors with a constant liquid volume of $0.8 \mathrm{l}$, that were sparged daily with sterile nitrogen and constantly maintained under a low pressure. The reactors were equipped with $\mathrm{pH}$ regulation (2300 Ingold transmitter controlling $5 \mathrm{M} \mathrm{NaOH}$ addition) and magnetic stirring. Temperature was maintained at $30^{\circ} \mathrm{C}$ by a thermostatted water circulation system.

Analysis. Biomass concentration was determined by measurements of cell dry weight using a predetermined correlation between $\mathrm{OD}_{620}$ (Uvikon 930 spectrophotometer) and cell dry weight. Fermentation products were quantified by HPLC. Fermenter gas effluents were analysed by gas chromatography. All the operating conditions have been described previously (Barbirato et al., 1995).

Preparation of cells and cell-free extracts. Cells $(25-30 \mathrm{mg}$ dry wt) were harvested from steady-state chemostat cultures, transferred to a nitrogen-purged tube and centrifuged immediately for $8 \mathrm{~min}$ at $8000 \mathrm{~g}$ and $4^{\circ} \mathrm{C}$ (J2-MC, Beckmann). The supernatant was discarded, and the cell pellet was stored under a nitrogen atmosphere at $-80^{\circ} \mathrm{C}$ until the preparation of cell-free extracts.

Cell-free extract preparation conditions depended on the enzyme activities. For alcohol dehydrogenase, aldehyde dehydrogenase, phosphotransacetylase, formate dehydrogenase and pyruvate formate-lyase, all manipulations were performed in an anaerobic workstation (Model bubble system, La Cahlène) maintained under a gaseous mixture $\left(80 \% \mathrm{~N}_{2} / 10 \%\right.$ $\mathrm{CO}_{2} / 10 \% \mathrm{H}_{2}$ ) and with oxygen-free solutions. Activities of these enzymes were greatly enhanced under these conditions in comparison to those measured under aerobic conditions. After slow thawing, the harvested cells were washed with $5 \mathrm{ml}$ $100 \mathrm{mM}$ oxygen-free potassium phosphate buffer (KPB) at $\mathrm{pH} 7.4$ and centrifuged for $5 \mathrm{~min}$ at $4000 \mathrm{~g}$. The cell pellet was then resuspended in $3 \mathrm{ml} 100 \mathrm{mM} \mathrm{KPB} \mathrm{(pH} \mathrm{7.4)} \mathrm{con-}$ taining $2 \mathrm{mM}$ dithiothreitol (DTT). Cell suspensions were sonicated in conical tubes at $4{ }^{\circ} \mathrm{C}$ with an ultrasonic disintegrator (Vibracell 72434, Bioblock) for 3 cycles of $30 \mathrm{~s}$ with $4 \mathrm{~min}$ cooling intervals. Cell debris was removed by centrifugation at $13000 \mathrm{~g}$ for $4 \mathrm{~min}$ (Hettich Microliter Centrifugal, Bioblock).

For glycerol dehydrogenase, glycerol-3-phosphate dehydrogenase, dihydroxyacetone kinase, glycerol kinase, lactate dehydrogenase, glyceraldehyde-3-phosphate dehydrogenase and acetate kinase, cell-free extracts were prepared under aerobic conditions. The harvested cells were washed with $5 \mathrm{ml}$ $100 \mathrm{mM} \mathrm{KPB} \mathrm{(pH} \mathrm{7.5).} \mathrm{After} \mathrm{centrifugation} \mathrm{for} 12 \mathrm{~min}$ at $12000 \mathrm{~g}$ and $4{ }^{\circ} \mathrm{C}$, the washed pellet was resuspended in $3 \mathrm{ml}$ of the same buffer. Cells were then disrupted at $4^{\circ} \mathrm{C}$ with a mechanical cell breaker with $3 \mathrm{~g}$ glass beads $(0.1 \mu \mathrm{m})$ for 8 cycles of $1 \mathrm{~min}$ with $4 \mathrm{~min}$ cooling intervals. Using these conditions, protein extraction was as efficient as using the ultrasonic disintegrator without affecting enzyme activities. Cell debris and glass beads were removed by centrifugation at $15000 \mathrm{~g}$ for $15 \mathrm{~min}$.

For the activities of 1,3-propanediol dehydrogenase, pyruvate dehydrogenase, ferricyanide-NADH oxidoreductase and pyruvate kinase, the same operating conditions were used with $100 \mathrm{mM}$ MOPS ( $\mathrm{pH} 7.5$ ) instead of KPB buffer.

Finally, for glycerol dehydratase, an oxygen-free $100 \mathrm{mM}$ glycine/ $\mathrm{KOH}$ buffer (pH 8.1) containing $250 \mathrm{mM} \mathrm{KCl}$ and $1 \%(\mathrm{w} / \mathrm{v})$ glycerol was used for washing and disrupting steps. Cells were disrupted with the mechanical cell breaker because this method allowed a higher recovery of this enzyme activity in comparison with the ultrasonic disintegrator treatment. Anaerobic conditions were maintained using a nitrogen flux at each step of the cell-free extract preparation.

Cell-free extracts were stored at $4{ }^{\circ} \mathrm{C}$ until the assay procedure.

Enzyme assays. Enzyme activities were systematically determined in their physiological direction at $30^{\circ} \mathrm{C}$. All reagent solutions were prepared in deionized water and degassed if necessary. A Uvikon 930 spectrophotometer (Kontron) was used for the enzyme assays performed under aerobic conditions. A Lambda 3 spectrophotometer (Perkin Elmer) was employed for the assays carried out in the anaerobic workstation. One unit of enzyme activity is defined as the amount of enzyme that catalyses the conversion of $1 \mu \mathrm{mol}$ substrate $\min ^{-1}$.

Glycerol dehydrogenase (EC 1.1.1.6) activity (Glyc DH) was measured by following the glycerol-dependent formation of FADH at $340 \mathrm{~nm}$ (Ruch et al., 1974). The assay mixture contained $100 \mathrm{mM}$ potassium bicarbonate $(\mathrm{pH} 9 \cdot 0), 2 \mathrm{mM}$ FAD, $30 \mathrm{mM}\left(\mathrm{NH}_{4}\right)_{2} \mathrm{SO}_{4}$ and $200 \mathrm{mM}$ glycerol $\left(\varepsilon_{340}=\right.$ $\left.6.22 \mathrm{mM}^{-1} \mathrm{~cm}^{-1}\right)$.

Glycerol-3-phosphate dehydrogenase (EC 1.1.99.5) (G3P $\mathrm{DH}$ ) was measured by following the G3P-dependent formation of $\mathrm{NADH}$. The assay system contained $50 \mathrm{mM}$ potassium bicarbonate ( $\mathrm{pH} 9.0$ ), $0.5 \mathrm{mM}$ NAD and $5 \mathrm{mM} \mathrm{G} 3 \mathrm{P}$.

Dihydroxyacetone (DHA) kinase (EC 2.7.1.29) activity was followed in a coupled system in which NADH-dependent reduction of the reaction product, dihydroxyacetone phosphate (DHAP), to G3P was measured in a modified assay based on that described by Johnson et al. (1984). The assay mixture contained $50 \mathrm{mM}$ potassium bicarbonate $(\mathrm{pH} 9 \cdot 0)$, $2.5 \mathrm{mM}$ ATP, $0.4 \mathrm{mM} \mathrm{NADH}, 15 \mathrm{mM} \mathrm{MgCl}_{2}, 2 \mathrm{mM}$ DTT, $18 \mathrm{U}$ glycerophosphate dehydrogenase from rabbit muscle 
and $10 \mathrm{mM}$ DHA. To prevent any secondary reaction (with Glyc DH), $15 \mathrm{mM} \alpha, \alpha^{\prime}$-dipyridyl was systematically added to the assay mixture (Lin \& Magasanik, 1960).

Glycerol kinase (EC 2.7.1.30) activity was measured by the procedure adopted from Kremer \& Hansen (1987). The assay mixture contained $100 \mathrm{mM}$ potassium bicarbonate $(\mathrm{pH} 9 \cdot 0$ ), $2.5 \mathrm{mM}$ ATP, $0.4 \mathrm{mM}$ NADH, $15 \mathrm{mM} \mathrm{MgCl}_{2}, 10 \mathrm{U} \mathrm{G} 3 \mathrm{P} \mathrm{DH}$ from rabbit muscle and $20 \mathrm{mM}$ glycerol.

1,3-Propanediol dehydrogenase (EC 1.1.1.202) activity (PPD $\mathrm{DH}$ ) was determined at $340 \mathrm{~nm}$ by measuring the initial rate of 3-hydroxypropionaldehyde (3-HPA) -dependent NADH decrease. The reaction mixture contained $200 \mathrm{mM} \mathrm{KPB}$ (pH 7.8), 0.4 mM NADH, 0.4 $\mathrm{mM} \mathrm{MnCl}_{2}$ and $3 \mathrm{mM} 3-\mathrm{HPA}$.

Coenzyme $\mathrm{B}_{12}$-dependent glycerol dehydratase (EC 4.2.1.30) activity (Glyc DA) was determined by the 3-methyl-2benzothiazolinone hydrazone (MBTH) method described by Toraya et al. (1977). It is based on the ability of the reaction product (3-HPA) to react with MBTH generating hydrazine derivatives which are spectrophotometrically quantifiable. The assay system, containing oxygen-free solutions, consisted of $5 \mathrm{mM} \mathrm{KPB} \mathrm{(pH} \mathrm{9.0),} 50 \mathrm{mM} \mathrm{KCl}, 25 \mathrm{mM} \mathrm{MnCl}_{2}, 15 \mathrm{mM}$ $\left(\mathrm{NH}_{4}\right)_{2} \mathrm{SO}_{4}, 25 \mathrm{mM}$ glycerol and $0.5 \mathrm{mM} \mathrm{ATP}$ as enzyme activator (Honda et al., 1980). After $10 \mathrm{~min}$ incubation at $37^{\circ} \mathrm{C}, 12 \mu \mathrm{M}$ coenzyme $\mathrm{B}_{12}$ was added to the assay mixture and the enzyme reaction was stopped at 0,1 and 2 min respectively by transferring $200 \mu \mathrm{l}$ of the assay mixture into a mixture containing $0.5 \mathrm{ml} 0.1 \%(\mathrm{w} / \mathrm{v}) \mathrm{MBTH}$ and $1 \mathrm{ml}$

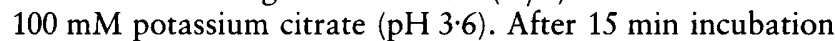
at $37^{\circ} \mathrm{C}$, the 3-HPA formed was calculated from the absorbance at $305 \mathrm{~nm}$ relative to a standard curve.

Glyceraldehyde-3-phosphate dehydrogenase (EC 1.2.1.12) activity (GAP DH) was estimated by a procedure adopted from Lovitt et al. (1988). The assay system contained $100 \mathrm{mM}$ Tricine/ $\mathrm{NaOH}$ buffer (pH 8.1), $10 \mathrm{mM} \mathrm{KH}_{2} \mathrm{AsO}_{4}, 1 \mathrm{mM}$ NAD, $7.5 \mathrm{mM} \mathrm{K}_{2} \mathrm{HPO}_{4}, 2 \mathrm{mM}$ DTT, $4 \mathrm{U}$ aldolase from baker's yeast and $4 \mathrm{mM}$ fructose- 1,6-biphosphate (FBP).

Pyruvate kinase (EC 2.7.1.40) activity was determined by following the $\mathrm{NADH}$-dependent reduction of the reaction product (pyruvate) to lactate at $340 \mathrm{~nm}$ (Hess \& Wieker, 1974). The reaction mixture consisted of $100 \mathrm{mM}$ triethanolamine ( $\mathrm{pH} 7.6$ ), 0.2 mM NADH, $5 \mathrm{mM} \mathrm{ADP}, 10 \mathrm{mM}$ $\mathrm{KCl}, 2 \mathrm{mM} \mathrm{CoCl}_{2}, 2 \mathrm{mM} \mathrm{MnCl}, 25 \mathrm{U}$ lactate dehydrogenase (LDH) from rabbit muscle and $10 \mathrm{mM}$ phosphoenolpyruvate (PEP).

Pyruvate dehydrogenase complex (EC 1.2.2.2) activity (PDH) was measured by following, at $430 \mathrm{~nm}$, the NADHdependent reduction of ferricyanide to ferrocyanide through the NADH-ferricyanide oxidoreductase naturally present in cell-free extracts (Carlsson et al., 1985). The assay mixture contained $50 \mathrm{mM}$ Tricine $/ \mathrm{KOH}(\mathrm{pH} 7 \cdot 0), 0.3 \mathrm{mM}$ thiamine pyrophosphate (TPP), 0.1 mM CoASH, $1 \mathrm{mM}$ NAD, $1 \mathrm{mM}$ potassium ferricyanide, $25 \mathrm{mM} \mathrm{Na}_{2} \mathrm{HPO}_{4}$ (pH 7.0), $30 \mathrm{mM}$ $\mathrm{MgCl}_{2}$ and $20 \mathrm{mM}$ pyruvate. Activity of NADH-ferricyanide oxidoreductase was measured by following the reduction of ferricyanide in a reaction mixture containing $100 \mathrm{mM}$ Tricine/KOH (pH 7.0), $50 \mathrm{mM} \mathrm{Na}_{2} \mathrm{HPO}_{4}$ (pH 7.0), $1 \mathrm{mM}$ potassium ferricyanide and $0.4 \mathrm{mM}$ NADH. This latter activity was systematically at least 200 -fold higher than $\mathrm{PDH}$ activity $\left(\varepsilon_{430}=1.03 \mathrm{mM}^{-1} \mathrm{~cm}^{-1}\right)$.

Pyruvate formate-lyase (EC 2.3.1.54) activity (PFL) was determined with a procedure adopted from Abbe et al. (1982). The assay mixture contained $100 \mathrm{mM} \mathrm{KPB}(\mathrm{pH} \mathrm{7.4),} 1 \mathrm{mM}$
NAD, $2 \mathrm{mM}$ DTT, $0.1 \mathrm{mM}$ CoASH, $14 \mathrm{U}$ malic dehydrogenase from bovine heart, $10 \mathrm{U}$ citrate synthase from porcine heart, $20 \mathrm{mM}$ pyruvate and $6 \mathrm{mM}$ malate.

Formate dehydrogenase activity (EC 1.2.1.2) was assayed in a reaction mixture, adopted from Snoep et al. (1990), containing $100 \mathrm{mM} \mathrm{KPB}, 1 \mathrm{mM} \mathrm{NAD}$ and $100 \mathrm{mM}$ formate.

Lactate dehydrogenase (EC 1.1.2.3) activity (LDH) was measured by following the NADH dependent reduction of pyruvate into lactate at $340 \mathrm{~nm}$ (Abbe et al., 1982). The assay mixture contained $20 \mathrm{mM} \mathrm{KPB}$ (pH 7.4), $0.4 \mathrm{mM} \mathrm{NADH}$, $1 \mathrm{mM} F B P$ and $20 \mathrm{mM}$ pyruvate.

Phosphotransacetylase (EC 2.3.1.8) activity was determined by following, at $405 \mathrm{~nm}$, the reaction between the coenzyme A liberated and 5,5'-dithiobis(2-nitrobenzoic acid) (DTNB) (Andersch et al., 1983). The reaction system contained $100 \mathrm{mM}$ KPB (pH 7.4), $0.2 \mathrm{mM}$ DTNB and $0.3 \mathrm{mM}$ acetyl$\operatorname{CoA}\left(\varepsilon_{405}=13.6 \mathrm{mM}^{-1} \mathrm{~cm}^{-1}\right)$.

Acetate kinase (EC 2.7.2.1) activity was measured according to the assay adopted from Lamed \& Zeikus (1980). The reaction mixture contained $80 \mathrm{mM}$ Tris/ $\mathrm{HCl}$ buffer $(\mathrm{pH} \mathrm{7 \cdot 2}$ ), $2 \mathrm{mM}$ ADP, $1 \mathrm{mM}$ NADP, $1 \mathrm{mM}$ DTT, $15 \mathrm{mM} \mathrm{MgCl}_{2}$, $20 \mathrm{mM}$ glucose, $2 \mathrm{U}$ hexokinase from baker's yeast, $2 \mathrm{U}$ glucose-6-phosphate dehydrogenase from baker's yeast and $10 \mathrm{mM}$ acetylphosphate.

Aldehyde dehydrogenase (EC 1.2.1.10) was assayed by following the NADH-dependent reduction of acetyl-CoA (Dürre et al., 1987). The assay system consisted of $100 \mathrm{mM}$ potassium bicarbonate (pH 9.0), 0.2 mM NADH, $2 \mathrm{mM}$ DTT, $40 \mathrm{mM}$ semicarbazide and $0.6 \mathrm{mM}$ acetyl-CoA.

Alcohol dehydrogenase (EC 1.1.1.1) activity (ADH) was determined by following the NADH-dependent reduction of acetaldehyde at $340 \mathrm{~nm}$. The assay mixture contained $100 \mathrm{mM}$ $\mathrm{KPB}$ (pH 7.4), 0.2 mM NADH, $2 \mathrm{mM}$ DTT and $40 \mathrm{mM}$ acetaldehyde (Lamed \& Zeikus, 1980).

Protein concentration was determined by use of the Coomassie Brilliant Blue G250 protein assay reagent supplied commercially by Bio-Rad with bovine serum albumin as standard.

Nucleotide extraction. NADH, NAD, ATP and ADP levels were measured after extraction of a culture broth sample as described by Vasconcelos et al. (1994). Samples collected were immediately transferred (in less than $5 \mathrm{~s}$ ) into the extraction solution $(\mathrm{NaOH}$ or $\mathrm{HCl})$. $\mathrm{NADH}$ was extracted at $\mathrm{pH} 12 \cdot 3$ with $10 \mathrm{M} \mathrm{KOH}$. After a $10 \mathrm{~min}$ incubation at $30^{\circ} \mathrm{C}$, the alkaline solution was centrifuged for $8 \mathrm{~min}$ at $5000 \mathrm{~g}$ and $4{ }^{\circ} \mathrm{C}$ and the supernatant was collected. NAD, ATP and ADP were extracted at $\mathrm{pH} 1.3$ with $6 \mathrm{M} \mathrm{HCl}$ by incubation for $10 \mathrm{~min}$ at $50{ }^{\circ} \mathrm{C}$. After centrifugation for $8 \mathrm{~min}$ at $5000 \mathrm{~g}$ and $4^{\circ} \mathrm{C}$, a third of the supernatant was collected and stored for ATP determination. The second third was progressively neutralized with $2 \mathrm{M} \mathrm{NaOH}$ for NAD assay. For the ADP determination, ADP was converted to ATP by creatine phosphokinase in a reaction mixture containing the last third of the supernatant, $50 \mathrm{mM}$ glycine buffer ( $\mathrm{pH} \mathrm{9.0),} 0.4 \mathrm{mM} \mathrm{MgSO}_{4}$ and $7 \mathrm{U}$ creatine phosphokinase from rabbit muscle maintained for $20 \mathrm{~min}$ at $30^{\circ} \mathrm{C}$. The reaction was stopped by addition of $\mathrm{HCl}$ (pH 2.0) and the mixture centrifuged. Samples were stored at $-80^{\circ} \mathrm{C}$ until the assay.

Nucleotide pool assays. Nucleotide pools were measured by use of a Hitachi fluorimeter (model F-2000) according to procedures adopted from Le Bloas (1992). The wavelength of the fluorescence excitation and emission were, respectively, 
340 and $460 \mathrm{~nm}$. Nucleotide concentrations were deduced from a calibration curve of pure commercial NADH in a concentration range $0 \cdot 1-7 \mu \mathrm{M}$. Dilutions were performed in $80 \mathrm{mM}$ triethanolamine buffer ( $\mathrm{pH} 7 \cdot 6$ ), $0.8 \mathrm{mM}$ EDTA and $3 \mathrm{mM} \mathrm{MgSO}_{4}$.

NADH concentration was determined by measuring the fluorescence decrease linked to the NADH-dependent conversion of pyruvate into lactate. The reaction mixture contained $100 \mathrm{mM}$ triethanolamine (pH 7.6), $3 \mathrm{mM} \mathrm{MgSO}_{4}$, $0.8 \mathrm{mM}$ EDTA, $4 \mathrm{mM}$ pyruvate and $25 \mathrm{ULDH}$ from rabbit muscle.

NAD pools were estimated by quantifying the increase in fluorescence following the oxidation of ethanol. The assay

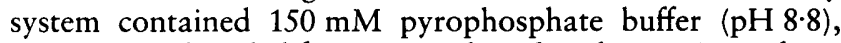
$0.8 \mathrm{~g}$ semicarbazide $\mathrm{l}^{-1}, 10 \mathrm{mM}$ ethanol and $27 \mathrm{U} \mathrm{ADH}$ from baker's yeast.

ATP concentration was determined by a coupled system in which decrease in NADH was followed. The assay mixture contained $100 \mathrm{mM}$ triethanolamine $(\mathrm{pH} 7 \cdot 6), 5 \mu \mathrm{M} \mathrm{NADH}$, $3 \mathrm{mM} \mathrm{MgSO}, 0.8 \mathrm{mM}$ EDTA, $2 \mathrm{mM}$ 3-phosphoglycerate, $9 \mathrm{U}$ G3P DH from rabbit muscle and $25 \mathrm{U} 3$-phosphoglyceric phosphokinase from baker's yeast.

Intermediate metabolite assays. Triose phosphates, GAP and dihydroxyacetone phosphate (DHAP), and FBP were extracted at acid $\mathrm{pH}$ as described for NAD and stored at $-80^{\circ} \mathrm{C}$ until assay. Assays were performed with an SLM-Aminco photon counting spectrofluorimeter (model $8000 \mathrm{C}$ ). Excitation and emission wavelengths were as described for the nucleotide pools. A calibration curve was created with pure commercial $\mathrm{NADH}$. The reaction mixture contained $50 \mathrm{mM} \mathrm{MES}$ (pH 6.5), $50 \mathrm{mM} \mathrm{KCl}, 5 \mathrm{mM} \mathrm{MgCl}, 0.05 \mathrm{mM} \mathrm{Na}_{2} \mathrm{CO}_{3}$ and $12.5 \mu \mathrm{M}$ NADH and extract. DHAP concentration was deduced from the variation of $\mathrm{NADH}$ emission after addition of 4.2 U G3P DH to the assay mixture; the concentration of GAP was determined after addition of $100 \mathrm{U}$ triose phosphate isomerase and FBP content was deduced from the variation of the NADH emission after addition of $2.5 \mathrm{U}$ aldolase.

Transmembrane $\mathrm{pH}$ determination. The $\Delta \mathrm{pH}$ was assayed by measuring the accumulation of $\left[{ }^{14} \mathrm{C}\right]$ benzoate by the oil centrifugation technique (Loubière et al., 1992). After concentration of the fermentation sample by centrifugation $(8000 \mathrm{~g}$ for $8 \mathrm{~min}$ ) and suspension of the pellet in $0.5 \mathrm{ml}$ supernatant, the cell suspension was incubated for $10 \mathrm{~min}$ at $30^{\circ} \mathrm{C}$ with $3.3 \mu \mathrm{M}\left[{ }^{14} \mathrm{C}\right]$ benzoate $\left(14.1 \times 10^{8} \mathrm{~Bq} \mathrm{mmol}^{-1}\right)$ and centrifuged $(14000 \mathrm{~g}$ for $15 \mathrm{~min}$ at room temperature) in the presence of $0.6 \mathrm{ml}$ of a mixture of miscible immersion oils containing $7 \%(\mathrm{w} / \mathrm{w})$ from Merck and $93 \%(\mathrm{w} / \mathrm{w})$ from Carlo Erba. Supernatant fractions were collected and transferred into vials containing $10 \mathrm{ml}$ of Ready Protein ${ }^{+}$scin- $^{-}$ tillation cocktail (Beckman). Radioactivity content was measured using a Packard liquid scintillation analyser. The remaining supernatant and the oil fraction were removed, and the wall of the centrifuge tube was carefully wiped clean. Fivehundred microlitres of $0.5 \mathrm{M} \mathrm{NaOH}$ was added to the cell pellet. After homogenization, the suspension was incubated for lysis at room temperature for $30 \mathrm{~min}$ and transferred into counting vials containing $10 \mathrm{ml}$ scintillation cocktail. The intracellular benzoate concentration was calculated together with the internal volume.

For the measurement of intracellular volume, the same amount of cell suspension was used. Incubation of the cell suspension was performed with $0.74 \times 10^{6} \mathrm{~Bq}^{3} \mathrm{H}_{2} \mathrm{O}\left(0.37 \times 10^{8} \mathrm{~Bq} \mathrm{ml}^{-1}\right)$ and $\quad 13.7 \times 10^{4} \mathrm{~Bq}{ }^{14} \mathrm{C}-\mathrm{PEG} \quad 4000 \quad\left(5.92 \times 10^{8} \mathrm{~Bq} \mathrm{~g}^{-1}\right)$.
Conditions were the same as described above. Intracellular volume, deduced from the differential partitioning of ${ }^{3} \mathrm{H}_{2} \mathrm{O}$ and ${ }^{14} \mathrm{C}-\mathrm{PEG}$, allowed the calculation of the intracellular benzoate concentration. Intracellular $\mathrm{pH}$ was deduced from the internal and external benzoate concentrations as described by Padan et al. (1981).

Calculations. For the glucose and glycerol-fed cultures, the ATP yield is defined as $Y_{\mathrm{ATP}}=D \times 1000 /\left[2 \times\left(q_{\text {Acet }}+\right.\right.$ $\left.\left.q_{\text {Lact }}+q_{\text {Succ }}+q_{\text {Etol }}\right)\right]$ where $q_{\text {Acet }}, q_{\text {Etol }}, q_{\text {Lact }}$, and $q_{\text {Suce }}$ are the specific rates (expressed in $\mathrm{mmol} \mathrm{g}^{-1} \mathrm{~h}^{-1}$ ) of production of acetate, ethanol, lactate and succinate, respectively. $D$ is the dilution rate $\left(\mathrm{h}^{-1}\right) . Y_{\mathrm{ATP}}$ is expressed as $\mathrm{g}$ cell per mol ATP produced.

The energetic efficiency (Eff) corresponds to Eff $=$ $D \times 1000 /\left(q_{\text {Glyc }} \times Y_{\text {ATP }}\right)$ where $q_{\text {Glyc }}$ is the specific rate of glycerol consumed. Eff is expressed as mol ATP formed per mol glycerol consumed.

For the glycerol-fed culture, the specific rate of formation of NAD is $q_{\mathrm{NAD}}=q_{\mathrm{PPD}}+q_{\mathrm{Lact}}+2 q_{\mathrm{Etol}}+2 q_{\mathrm{succ}}$ where $q_{\mathrm{PPD}}$ is the specific rate of production of PPD.

For PDH activity, the specific rate of formation of NADH is $q_{\mathrm{NADH}}=3 q_{\mathrm{Acet}}+3 q_{\mathrm{Etol}}-q_{\mathrm{Form}}+2 q_{\mathrm{Lact}}+2 q_{\mathrm{succ}}+8.035 \mu . q_{\mathrm{Form}}$ is the specific rate of formation of formate, 8.035 is the amount, expressed in $\mathrm{mmol}(\mathrm{g} \text { cells })^{-1}$, of the $\mathrm{NADH}$ requirement for the biomass formation with glycerol as substrate (Ingraham et al., 1983).

For the glucose-fed culture, the specific rate of formation of NAD is the same as described above. The specific rate of formation of $\mathrm{NADH}$ is $q_{\mathrm{NADH}}=$ $2 q_{\text {Acet }}+2 q_{\text {Etol }}-q_{\text {Form }}+q_{\text {Lact }}+q_{\text {suce }}+14.678 \mu$ where 14.678 is the amount, expressed in mmol (g cells) ${ }^{-1}$, of the NADH requirement for the biomass formation with glucose as substrate (Ingraham et al., 1983).

The redox recovery is defined as $100\left(q_{\mathrm{NAD}} / q_{\mathrm{NADH}}\right)$.

Chemicals. All chemicals, enzymes and co-enzymes were purchased from Sigma. The radiochemical compounds, ${ }^{3} \mathrm{H}_{2} \mathrm{O}$ and ${ }^{14} \mathrm{C}-\mathrm{PEG}$ were purchased from Amersham, and ${ }^{14} \mathrm{C}$ benzoate from ICN Pharmaceuticals. 3-HPA was synthesized from acrolein by the method of Hall \& Stern (1950).

\section{RESULTS}

\section{Comparison of the glycerol- and glucose-fed continuous cultures}

(i) Fermentation profile. E. agglomerans was grown anaerobically at $\mathrm{pH} 7$ in chemostat culture at a dilution rate of $0.05 \mathrm{~h}^{-1}$ under glycerol or glucose limitation. Fermentation profiles, shown in Table 1, showed that acetic acid, ethanol and formic acid were the main products of the glucose fermentation. Lactic and succinic acids were only produced as by-products of the fermentation. Very low amounts of PPD and 2,3butanediol were measured. In contrast, with glycerol as carbon source, PPD was the major fermentation product. Acetic acid, ethanol and formic acid were the main by-products, while lactic and succinic acids were produced in small quantities. No significant microbial energetic changes were observed when using these two different substrates, the ATP yields being almost similar. Biomass concentration was higher with glucose than 
Table 1. Fermentation product profiles of $E$. agglomerans grown anaerobically under glucose- and glycerol-limited continuous cultures

Data are given with a $3 \%$ precision. Carbon recovery is defined as the amount of carbon that is retrieved in biomass and analysed products. Redox recovery is defined in Methods.

\begin{tabular}{|c|c|c|c|c|c|c|}
\hline \multirow{2}{*}{\multicolumn{2}{|c|}{$\begin{array}{r}D\left(\mathrm{~h}^{-1}\right): \\
\text { Substrate: }\end{array}$}} & \multicolumn{2}{|c|}{0.05} & $0 \cdot 15$ & $0 \cdot 25$ & $0 \cdot 31$ \\
\hline & & Glucose & Glycerol & \multicolumn{3}{|c|}{ Glycerol } \\
\hline Residual conc $\left(\mathrm{g} \mathrm{I}^{-1}\right)$ & & $<0.1$ & $<0.1$ & 0.2 & $1 \cdot 0$ & $1 \cdot 2$ \\
\hline Biomass $\left(\mathrm{g}^{-1}\right)$ & & $1 \cdot 6$ & 1.05 & $1 \cdot 06$ & 0.97 & 0.82 \\
\hline$Y_{\mathrm{ATP}}\left(\mathrm{g} \mathrm{mol}^{-1}\right)$ & & $6 \cdot 44$ & 6.89 & $7 \cdot 83$ & 7.92 & 7.02 \\
\hline$E f f\left(\mathrm{~mol} \mathrm{~mol}^{-1}\right)$ & & $2 \cdot 3$ & 0.71 & 0.63 & 0.59 & 0.57 \\
\hline \multicolumn{7}{|c|}{ Product yields $\left(\mathrm{mol} \mathrm{mol}^{-1}\right)$} \\
\hline 1,3-Propanediol & & $<0.013$ & 0.44 & 0.52 & 0.55 & 0.57 \\
\hline Acetate & & $0 \cdot 70$ & $0 \cdot 21$ & $0 \cdot 20$ & $0 \cdot 20$ & $0 \cdot 20$ \\
\hline Ethanol & & 0.73 & $0 \cdot 23$ & $0 \cdot 16$ & $0 \cdot 10$ & 0.07 \\
\hline Formate & & $1 \cdot 365$ & $0 \cdot 40$ & $0 \cdot 31$ & $0 \cdot 24$ & $0 \cdot 21$ \\
\hline Lactate & & $0 \cdot 066$ & $0: 020$ & $0 \cdot 055$ & $0 \cdot 080$ & $0 \cdot 090$ \\
\hline Succinate & & $0 \cdot 050$ & 0.035 & 0.014 & $0 \cdot 013$ & 0.012 \\
\hline 2,3-Butanediol & & $<0.013$ & 0 & 0 & 0 & 0 \\
\hline Carbon recovery $(\%)$ & & 89 & 100 & 100 & 99 & 98 \\
\hline Redox recovery (\%) & & 95 & 94 & 98 & 97 & 98 \\
\hline
\end{tabular}

with glycerol because of a greater efficiency of ATP generation per mol substrate. A good redox balance was obtained, with a reducing equivalent recovery of $94 \%$ on glycerol and $95 \%$ on glucose.

(ii) Enzymic study. Table 2 shows the enzyme profile of $E$. agglomerans grown in chemostat cultures. In contrast to the glucose-limited culture, glycerol leads to a 30-120fold increase in the levels of Glyc DH, DHA kinase, Glyc $\mathrm{DA}$ and PPD DH. The expression of the structural genes of these enzymes, encoded by the $d h$ a regulon, is subject to catabolite repression or is induced by glycerol in Klebsiella pneumoniae (Lin, 1976). A similar regulation seemingly occurs in E. agglomerans. Moreover, activities of glycerol kinase and G3P DH were not detected indicating that this metabolic route is not present under anaerobic conditions. Glycolytic enzymes exhibited higher levels of activity on glucose in comparison with the glycerol-limited culture. This is particularly pronounced for GAP DH. PFL activity was lower in the glycerol culture while PDH activity was detected in both cultures, which suggested that PFL is not the only enzyme generating acetyl-CoA from pyruvate. Formate dehydrogenase activity, belonging to the formate hydrogen-lyase complex, was not detected, which is in accordance with the findings of De Vos et al. (1983) who reported the inability of $E$. agglomerans to decompose formate into $\mathrm{CO}_{2}$ and $\mathrm{H}_{2}$, and those of Ewing \& Fife (1972) who described an extremely low gas production by this strain. Acetic-acid-producing enzymes were threefold higher on glucose than on glycerol. The ethanol production pathway exhibited a high level of aldehyde dehydrogenase activity on glucose while a lower ADH activity was observed on glucose, which shows that the most reduced substrate gave highest ADH activity as described by McPhedran et al. (1961).

(iii) Intracellular nucleotide and metabolite concentrations and $\mathbf{p H}$. The NAD:NADH ratio was slightly lower on glycerol $(2 \cdot 8)$ than on glucose $(3 \cdot 1)$ (Table 2 ). The ATP level was similar for the two cultures, while the ADP level was higher on glucose. DHAP and FBP concentrations were higher on the glycerol- than on the glucose-fed culture although the carbon flow at that level was lower. GAP concentration, in equilibrium with DHAP, remained low in both cultures. Transmembrane $\mathrm{pH}$ of Clostridium acetobutylicum was shown to be inverted when glycerol was co-added to a glucoselimited chemostat culture (Girbal et al., 1994). To investigate whether the same occurred in $E$. agglomerans, the $\Delta \mathrm{pH}$ was measured on glucose- and glycerol-fed cultures. An almost similar positive transmembrane $\mathrm{pH}$ was found in both conditions despite the different redox states of the substrates.

\section{Effect of the dilution rate on the glycerol-fed culture}

(i) Carbon flow distribution. As depicted in Table 1, increasing dilution rate resulted first in an incomplete substrate exhaustion particularly at $D=0.25 \mathrm{~h}^{-1}$ and $0.31 \mathrm{~h}^{-1}$. For such growth rates, biomass concentration decreased concomitantly with the ATP yield and the energetic efficiency. In terms of carbon flow distribution, we paid attention to three branching points. When growth rate was increased, the glycerol entering the cell was preferentially directed towards the PPD formation 


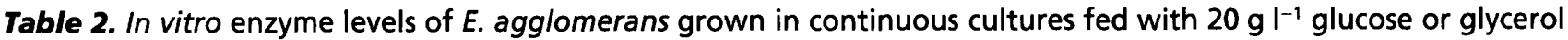

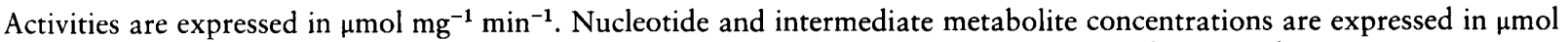
( $\mathrm{g}$ dry cell $w t)^{-1}$. Data in parentheses are SD deduced from eight determinations. ND, Not determined.

\begin{tabular}{|c|c|c|c|}
\hline$D\left(\mathbf{h}^{-1}\right):$ & \multicolumn{2}{|c|}{$0 \cdot 05$} & \multirow{2}{*}{$\begin{array}{c}0.31 \\
\text { Glycerol }\end{array}$} \\
\hline Substrate: & Glucose & Glycerol & \\
\hline \multicolumn{4}{|l|}{ Glycerol catabolism enzymes } \\
\hline Glycerol dehydrogenase & $0.16(0.028)$ & $13.03(2 \cdot 88)$ & $5 \cdot 36(0 \cdot 23)$ \\
\hline Dihydroxyacetone kinase & $0.305(0 \cdot 021)$ & $9 \cdot 34(1 \cdot 23)$ & $3.80(0.40)$ \\
\hline Glycerol dehydratase & $0.0045(0.0018)$ & $0 \cdot 18(0 \cdot 04)$ & $6 \cdot 15(0.99)$ \\
\hline 1,3-Propanediol dehydrogenase & $0.078(0.021)$ & $9 \cdot 16(2 \cdot 2)$ & $8.33(1.36)$ \\
\hline \multicolumn{4}{|l|}{ Central axis enzymes } \\
\hline Glyceraldehyde-3-phosphate dehydrogenase & $5 \cdot 51(0 \cdot 37)$ & $2 \cdot 31(0 \cdot 1)$ & $3 \cdot 37(0 \cdot 29)$ \\
\hline Pyruvate kinase & $1.35(0.09)$ & $0.80(0.08)$ & $1 \cdot 04(0 \cdot 15)$ \\
\hline Pyruvate formate lyase & $9 \cdot 35(1.50)$ & $3.42(0.31)$ & $4.95(0.86)$ \\
\hline Pyruvate dehydrogenase & $0.074(0.005)$ & $0.16(0.03)$ & $0.13(0.027)$ \\
\hline \multicolumn{4}{|l|}{ Acid producing enzymes } \\
\hline Phosphotransacetylase & $19 \cdot 11(2 \cdot 67)$ & $5 \cdot 31(0 \cdot 8)$ & $11.57(3.03)$ \\
\hline Acetate kinase & $51 \cdot 3(4 \cdot 7)$ & $17 \cdot 06(3 \cdot 01)$ & $30 \cdot 29(1.54)$ \\
\hline Lactate dehydrogenase & $1.26(0.09)$ & $1 \cdot 33(0 \cdot 20)$ & $0.68(0.04)$ \\
\hline \multicolumn{4}{|l|}{ Ethanol producing enzymes } \\
\hline Aldehyde dehydrogenase & $0.030(0.008)$ & $0.0035(0.0012)$ & $0.0022(0.0006)$ \\
\hline Alcohol dehydrogenase & $0.205(0.014)$ & $0.94(0.17)$ & $0.52(0.08)$ \\
\hline \multicolumn{4}{|l|}{ Nucleotide levels } \\
\hline $\mathrm{NADH}$ & $1 \cdot 39(0 \cdot 28)$ & $2 \cdot 38(0 \cdot 40)$ & $2 \cdot 26(0 \cdot 39)$ \\
\hline $\mathrm{NAD}^{+}$ & $4.28(0.39)$ & $6.78(0.53)$ & $7.79(0.83)$ \\
\hline ATP & $4.43(0.59)$ & $4.49(0.39)$ & $6.33(0.57)$ \\
\hline ADP & $2 \cdot 03(0.42)$ & $0.70(0.28)$ & $2 \cdot 19(0 \cdot 41)$ \\
\hline \multicolumn{4}{|l|}{ Intermediate metabolites } \\
\hline Dihydroxyacetone phosphate & $6.93(0.83)$ & $9.64(0.81)$ & $17 \cdot 35(2 \cdot 13)$ \\
\hline Glyceraldehyde 3-phosphate & $0.55(0.34)$ & $0.95(0.39)$ & $1.70(0.50)$ \\
\hline Fructose 1,6-bisphosphate & $1 \cdot 13(0.49)$ & $6.91(0.62)$ & $16.57(1.92)$ \\
\hline \multicolumn{4}{|l|}{ Transmembrane $\mathrm{pH}$} \\
\hline$\Delta \mathrm{pH}$ & $0.46(0.08)$ & $0 \cdot 37(0.07)$ & ND \\
\hline
\end{tabular}

route (Fig. 1): $44 \%$ at $D=0.05 \mathrm{~h}^{-1}$ and $57 \%$ at $D=$ $0 \cdot 31 \mathrm{~h}^{-1}$. At the pyruvate level, lactate synthesis was stimulated by increasing $D$ despite the shift of the carbon flow to acetyl-CoA. Finally, acetyl-CoA distribution towards acetate formation was favoured to the detriment of ethanol production, which resulted in a drop in the ethanol molar conversion yield from 0.23 to 0.07 when $D$ was raised from $0.05 \mathrm{~h}^{-1}$ to $0.31 \mathrm{~h}^{-1}$ (Table 1). As a consequence, the relative ratio between the specific rates of production of PPD and ethanol was enhanced from 1.9 at $D=0.05 \mathrm{~h}^{-1}$ to 8.1 at $D=$ $0.31 \mathrm{~h}^{-1}$. Similar results were reported for $K$. pneumoniae (Streekstra et al., 1987; Ogbe Solomon et al., 1994) and Citrobacter freundii (Boenigk et al., 1993). The contribution of the two parallel enzymic complexes, PFL and PDH, in the global carbon flow generating acetyl-CoA is illustrated in Fig. 1. It shows that in vivo PDH activity catalysed $9 \%$ and $22 \%$ of the pyruvate flow towards acetyl-CoA at $D=0.05 \mathrm{~h}^{-1}$ and $0.31 \mathrm{~h}^{-1}$, respectively. (ii) Enzyme activities. Evolution of glycerol catabolizing enzyme activities were different in the reductive or the oxidative branch (Table 2). Activities of Glyc DH and DHA kinase decreased 2.5-fold when $D$ increased from $0.05 \mathrm{~h}^{-1}$ to $0.31 \mathrm{~h}^{-1}$. By contrast, activity of Glyc DA showed a 34-fold increase while the level of PPD DH remained stable. Such an increase of Glyc DA activity as a result of increasing the growth rate has been reported previously in C. freundii grown in glycerol-limited continuous culture: it increased from $0.05 \mathrm{U} \mathrm{mg}^{-1}$ at $D$ $=0.08 \mathrm{~h}^{-1}$ to $1.3 \mathrm{U} \mathrm{mg}^{-1}$ at $D=0.36 \mathrm{~h}^{-1}$ (Boenigk et al., 1993). The preferential distribution of glycerol towards the PPD pathway at high dilution rates, reported above, was thus correlated with the increase of the relative ratio of Glyc DA to Glyc DH. Central axis enzymes presented a uniform 1.4-fold increase except for PDH activity which decreased slightly. Enzymes associated with acetic acid formation showed a twofold increase at high dilution rate. In contrast, $\mathrm{LDH}$ presented a twofold decrease of activity between 
(a)

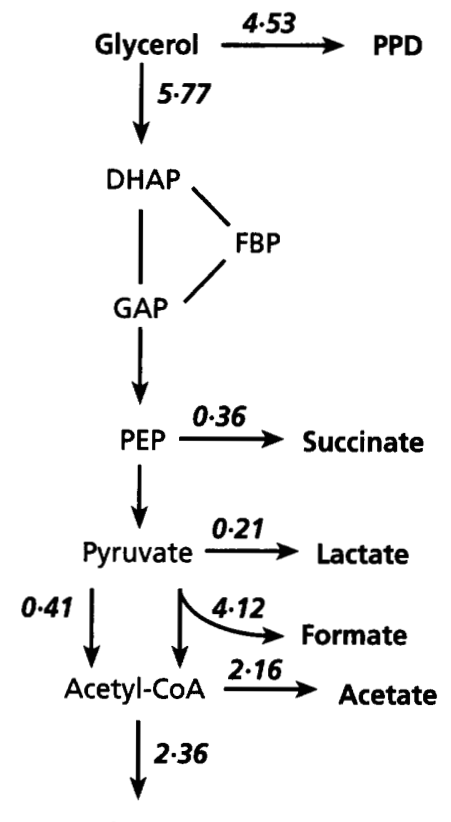

Ethanol (b)

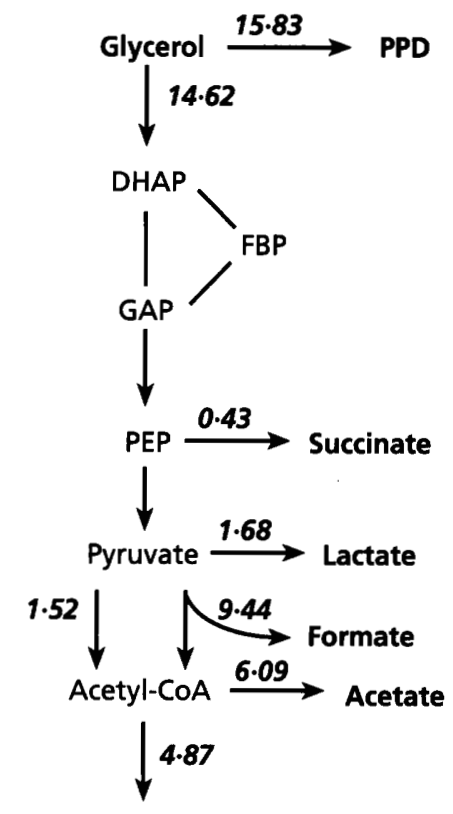

Ethanol (c)

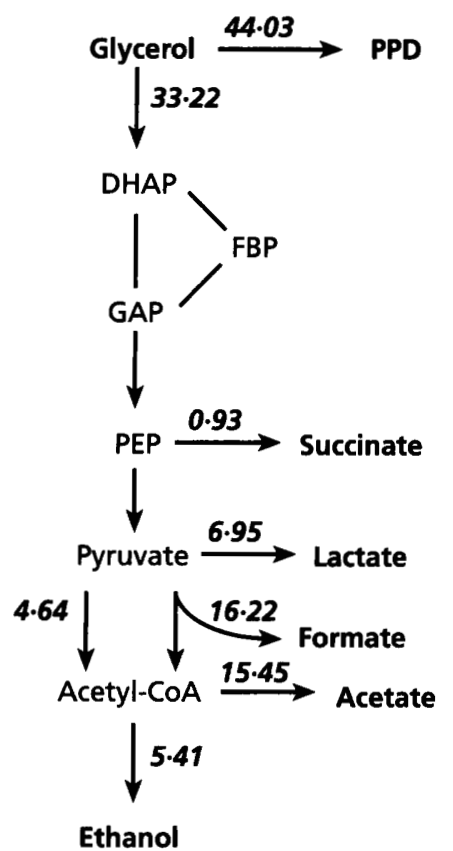

Fig. 1. Quantitative flow schemes at $D=0.05 \mathrm{~h}^{-1}(\mathrm{a}), 0.15 \mathrm{~h}^{-1}$ (b) and $0.31 \mathrm{~h}^{-1}$ (c). Values are expressed in $\mathrm{mmol}^{-1} \mathrm{~h}^{-1}$. Abbreviation: PEP, phosphoenolpyruvate.

$D=0.05 \mathrm{~h}^{-1}$ and $0.31 \mathrm{~h}^{-1}$, although in vivo activity was significantly enhanced. Levels of aldehyde dehydrogenase and ADH showed a 1.6- and 1.8-fold drop in activity, respectively, at high growth rate.

(iii) Intracellular nucleotide and metabolite concentrations. A slight increase in the NAD pool was observed, while the NADH pool was not affected (Table 2). Consequently, the relative ratio NAD: NADH increased from 2.85 at $D=0.05 \mathrm{~h}^{-1}$ to 3.45 at $D=0.31 \mathrm{~h}^{-1}$. ATP and ADP pools presented respectively a $1 \cdot 4$ - and $3 \cdot 1$-fold increase resulting in a $2 \cdot 2$-fold decrease of the ATP :ADP ratio. Triose-phosphates and FBP concentrations increased significantly at the higher dilution rate, while the GAP concentration remained low.

\section{DISCUSSION}

In $K$. pneumoniae anaerobic pathways of glycerol dissimilation involve the utilization of PFL to catalyse the oxidation of pyruvate to acetyl-CoA (Streekstra $e t$ al., 1987). When grown in batch culture under low initial glycerol content, and hence low glycerol uptake rate, E. agglomerans was thought to exclusively use PFL to funnel pyruvate to acetyl-CoA: a perfect relationship between the molar amount of formate and acetate plus ethanol was established (Barbirato et al., 1995). Nevertheless, this correlation was not verified when batch cultures were performed with higher glycerol concentrations. In the chemostat culture, an unbalanced relationship was noticed between the molar amount of formate and acetate plus ethanol produced in addition to the lack of formate dehydrogenase activity, suggesting the utilization of a parallel pathway for the conversion of pyruvate to acetyl-CoA. PDH activity is commonly observed under aerobic conditions whereas PFL, which shows extremely high sensitivity to molecular oxygen (Abbe et al., 1982), is expressed and is only active under strict anaerobiosis (Sawers \& Böck, 1988). However, $\mathrm{PDH}$ was shown to be active under anaerobiosis in Streptococcus mutants (Carlsson et al., 1985) and it was revealed that an important part of the pyruvate flow was shifted to $\mathrm{PDH}$ at high NAD:NADH ratios in Enterococcus faecalis (Snoep et al., 1990). In vitro $\mathrm{PDH}$ activity was detected in E. agglomerans in both glucoseand glycerol-fed cultures. Moreover, the redox balance was better equilibrated by supposing PDH activity, and the intracellular NAD: NADH ratio was also favourable to the in vivo activity of the enzyme. These results argue for the presence of PDH activity in E. agglomerans: between $9 \%$ and $22 \%$ of the pyruvate flow to acetyl$\mathrm{CoA}$ is shifted to $\mathrm{PDH} . \mathrm{CO}_{2}$ production from the decarboxylation of pyruvate by PDH was less than expected and its utilization by carboxylating steps in the metabolism is suspected, as well as its absorption by the feed medium with the formation of carbonate (Zeng, 1995). PDH activity thus occurred in E. agglomerans, as depicted in Fig. 2.

At the pyruvate branching point, distribution of the carbon flow through LDH, PFL and PDH activities occurred. The proportion of the pyruvate flow shifted to PFL represented $87 \%$ at $D=0.05 \mathrm{~h}^{-1}$ and only $58 \%$ at $D=0.31 \mathrm{~h}^{-1}$. Such behaviour probably results from a 


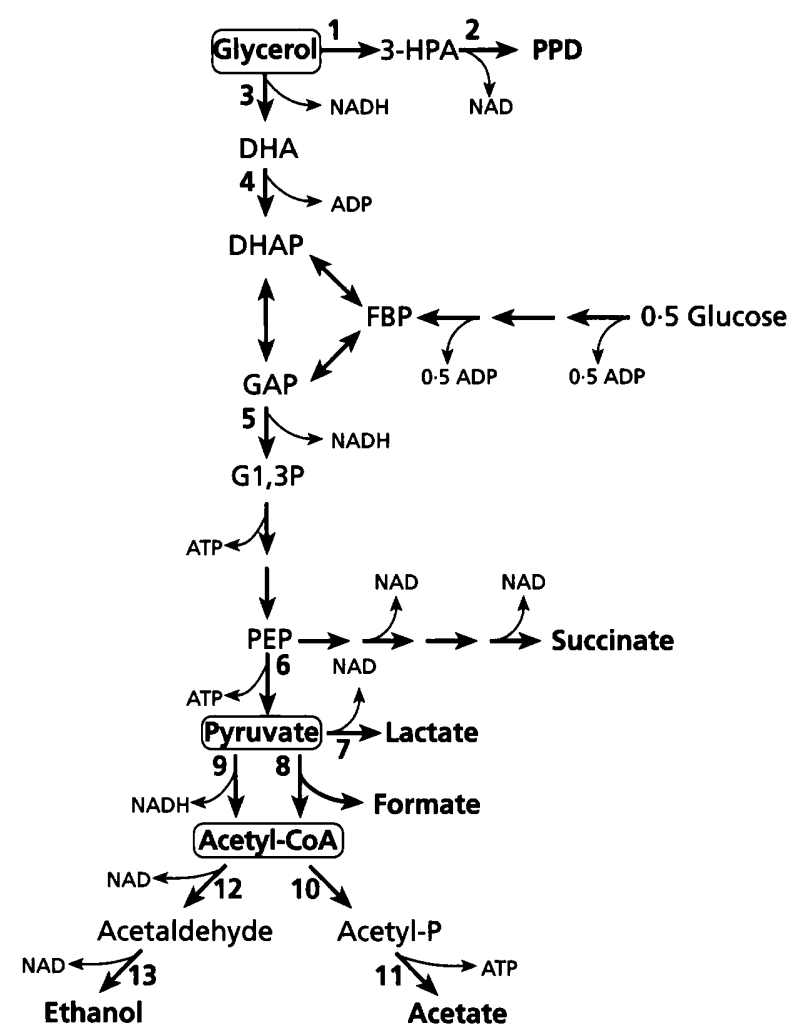

Fig. 2. Metabolic pathways involved in glycerol assimilation by E. agglomerans. Abbreviations: G1,3P, glyceraldehyde-1,3biphosphate; PEP, phosphoenolpyruvate; acetyl-P, acetyl phosphate. Enzymes: 1, Glyc DA; 2, PPD DH; 3, Glyc DH; 4, DHA kinase; 5, GAP DH; 6, pyruvate kinase; 7, LDH; 8, PFL; 9, $\mathrm{PDH}$. 10, phosphotransacetylase; 11 , acetate kinase; 12 , aldehyde $\mathrm{DH} ; 13, \mathrm{ADH}$.

carbon flow conversion limitation at the level of PFL. This phenomenon is particularly pronounced at high dilution rate when glycerol is provided in excess. PFL activity is known to be activated by pyruvate (Knappe $\&$ Sawers, 1990) and inhibited by triose-phosphates, GAP and DHAP (Takahashi et al., 1982). In comparison to levels reached in the glucose-fed culture, intracellular concentrations of triose-phosphates and FBP were higher in the culture supplied with glycerol. This is surely linked to the lower GAP DH activity measured in the latter culture, suggesting that this metabolic step is limiting. One can suspect that the relative drop in in vivo PFL activity, when dilution rate increases, results from a partial inhibition of PFL by intracellular triose phosphates, particularly DHAP. The enhanced in vivo PDH activity thus may allow the decarboxylation of the excess pyruvate (Hansen \& Henning, 1966) and hence the prevention of any deleterious effect by that compound (Collins, 1972), and also the increase in the global rate of NADH generation, limited at the level of the GAP DH, thus contributing to the redox balance. The increase of in vivo LDH activity may result from an intracellular accumulation of pyruvate (Tarmy \& Kaplan, 1968).
High rates of glycerol dissimilation thus involve both a preferential distribution towards the PPD metabolic pathway and a limitation by GAP DH. As glycerol is the branching point of the reductive and oxidative pathways, the carbon flux through the reductive branch is not exclusively controlled by the glycolytic flux. The PPD pathway acts as a pacemaker of the oxidative metabolism by increasing the regeneration, and hence the availability, of the NAD necessary at the glycolytic level to minimize the limiting step. This explains why a high NAD: NADH ratio is observed despite the fact that the organism is grown on a reduced substrate. Despite this 'overflow metabolism' (Streekstra et al., 1987), an accumulation of triose phosphates occurred, indirectly causing an enhanced pyruvate flow distribution toward $\mathrm{PDH}$ and LDH. Parameters such as pyruvate and triose phosphate intracellular concentrations and the $\mathrm{NAD}: \mathrm{NADH}$ ratio could play a key role in this proposed regulation. Obviously, this hypothetical regulation scheme at the level of the pyruvate branching point needs to be confirmed.

\section{ACKNOWLEDGEMENTS}

This research was supported by the Agence de l'Environnement et de la Maîtrise de l'Energie (ADEME), the Organisation Nationale Interprofessionnelle des Oléagineux (ONIDOL) and INRA. The authors thank Christel Garrigues and Muriel Cocaign (INSA, Toulouse, France) for their help in nucleotide concentration determinations and John Davison (INRA Narbonne, France) for correcting the English version of the manuscript.

\section{REFERENCES}

Abbad-Andaloussi, S., Durr, C., Raval, G. \& Petitdemange, H. (1996). Carbon and electron flow in Clostridium butyricum grown in chemostat culture on glycerol and on glucose. Microbiology 142, 1149-1158.

Abbe, K., Takahashi, S. \& Yamada, T. (1982). Involvement of oxygen-sensitive pyruvate formate-lyase in mixed-acid fermentation by Streptococcus mutans under strictly anaerobic conditions. J Bacteriol 152, 175-182.

Andersch, W., Bahl, H. \& Gottschalk, G. (1983). Level of enzymes involved in acetate butyrate, acetone and butanol formation by Clostridium acetobutylicum. Eur J Appl Microbiol Biotechnol 18, 327-332.

Barbirato, F., Bories, A., Camarasa-Claret, C. \& Grivet, J. P. (1995). Glycerol fermentation by a new 1,3-propanediol producing microorganism: Enterobacter agglomerans. Appl Microbiol Biotechnol 43, 786-793.

Barbirato, F., Grivet, J. P., Soucaille, P. \& Bories, A. (1996a). 3Hydroxypropionaldehyde, an inhibitory metabolite of the glycerol fermentation by enterobacterial species. Appl Environ Microbiol 62, 1448-1451.

Barbirato, F., Soucaille, P. \& Bories, A. (1996b). Physiologic mechanisms involved in accumulation of 3-hydroxypropionaldehyde during fermentation of glycerol by Enterobacter agglomerans. Appl Environ Microbiol 62, 4405-4409.

Biebl, H., Marten, S., Hippe, H. \& Deckwer, W. D. (1992). Glycerol conversion to 1,3-propanediol by newly isolated clostridia. Appl Microbiol Biotechnol 36, 592-597. 
Boenigk, R., Bowien, S. \& Gottschalk, G. (1993). Fermentation of glycerol to 1,3-propanediol in continuous cultures of Citrobacter freundii. Appl Microbiol Biotechnol 38, 453-457.

Carlsson, J., Kujala, U. \& Edlung, M. B. K. (1985). Pyruvate dehydrogenase activity in Streptococcus mutans. Infect Immun 49, 674-678.

Chowdhury, J. \& Fouhy, K. (1993). Vegetable oils: from table to gas tank. Chem Eng 100, 35-39.

Collins, E. B. (1972). Biosynthesis of flavour compounds by microorganisms. J Dairy Sci 55, 1022-1028.

De Vos, P., Stevens, P. \& De Ley, J. (1983). Hydrogen gas production from formate and glucose by different members of the Enterobacteriaceae. Biotechnol Lett 5, 69-74.

Durre, P., Kuhn, A., Gottwald, M. \& Gottschalk, G. (1987). Enzymatic investigations on butanol dehydrogenase and butyraldehyde dehydrogenase in extracts of Clostridium acetobutylicum. Appl Microbiol Biotechnol 26, 268-272.

Eggersdorfer, M., Meyer, J. \& Eckes, P. (1992). Use of renewable resources for non-food materials. FEMS Microbiol Rev 103, $355-364$

Elm, R., Falbe, J., Hahn, H. D. \& Gelbke, H. P. (1980). Propanediole. In Ullmanns Encyklopädie der technischen Chemie, vol. 19, pp. 425-432. Edited by E. Bartholomé, E. Biekert, H. Hellmann, H. Ley, M. Weigert \& E. Weise. Weinheim: Verlag Chemie.

Ewing, W. H. \& Fife, M. A. (1972). Enterobacter agglomerans (Beijerinck) comb. nov. (the Herbicola-Lathyri bacteria). Int $J$ Syst Bacteriol 22, 4-11.

Forsberg, C. W. (1987). Production of 1,3-propanediol from glycerol by Clostridium acetobutylicum and other Clostridium species. Appl Environ Microbiol 53, 639-643.

Girbal, L., Vasconcelos, I. \& Soucaille, P. (1994). Transmembrane $\mathrm{pH}$ of Clostridium acetobutylicum is inverted (more acidic inside) when the in vivo activity of hydrogenase is decreased. $J$ Bacteriol 176, 6146-6147.

Günzel, B., Yonsel, S. \& Deckwer, W. D. (1991). Fermentative production of 1,3-propanediol from glycerol by Clostridium butyricum up to a scale of $2 \mathrm{~m}^{3}$. Appl Microbiol Biotechnol 36, 289-294.

Hall, R. H. \& Stern, E. S. (1950). Acid-catalysed hydration of acraldehyde. Kinetics of the reaction and isolation of 3hydroxypropaldehyde. J Chem Soc (Lond), 490-498.

Hansen, R. G. \& Henning, U. (1966). Regulation of pyruvate dehydrogenase activity in Escherichia coli K12. Biochim Biophys Acta 122, 355-358.

Hess, B. \& Wieker, H. J. (1974). Pyruvate kinase from yeast. In Methods of Enzymatic Analysis, vol. 2, pp. 778-780. Edited by H. U. Bergmeyer. New York: Academic Press.

Homann, T., Tag, C., Biebl, H., Deckwer, W. D. \& Schink, B. (1990). Fermentation of glycerol to 1,3-propanediol by Klebsiella and Citrobacter strains. Appl Microbiol Biotechnol 33, 121-126.

Honda, S., Toraya, T. \& Fukui, S. (1980). In situ reactivation of glycerol-inactivated coenzyme $\mathrm{B}_{12}$-dependent enzymes, glycerol dehydratase and diol dehydratase. J Bacteriol 143, 1458-1465.

Ingraham, J. L., Maaloe, O. \& Neidhart, F. C. (1983). Growth of the bacterial cell. Sanderland, USA: Sinauer Associates.

Johnson, E. A., Burke, S. K., Forage, R. G. \& Lin, E. C. C. (1984). Purification and properties of dihydroxyacetone kinase from Klebsiella pneumoniae. J Bacteriol 160, 55-60.

Knappe, J. \& Sawers, G. (1990). A radical route to acetyl-CoA : the anaerobically induced pyruvate formate-lyase reaction in Escherichia coli. FEMS Microbiol Lett 75, 383-398.
Kremer, D. R. \& Hansen, T. A. (1987). Glycerol and dihydroxyacetone dissimilation in Desulfovibrio strains. Arch Microbiol 147, 249-256.

Lamed, R. \& Zeikus, J. G. (1980). Ethanol production by thermophilic bacteria : relationship between fermentation product yields and catabolic enzyme activities in Clostridium thermocellum and Thermoanaerobium brockii. J Bacteriol 144, 569-578.

Le Bloas, P. (1992). Etude des limitations et des régulations du métabolisme central de Eubacterium limosum. PhD Thesis, INSA, Toulouse, France.

Lin, E. C. C. (1976). Glycerol dissimilation and its regulation in bacteria. Annu Rev Microbiol 30, 535-578.

Lin, E. C. C. \& Magasanik, B. (1960). The activation of glycerol dehydrogenase from Aerobacter aerogenes by monovalent cations. J Biol Chem 235, 1820-1823.

Loubière, P., Salou, P., Leroy, M. J., Lindley, N. D. \& Pareilleux, A. (1992). Electrogenic malate uptake and improved growth energetics of the malolactic bacterium Leuconostoc oenos grown on glucose-malate mixtures. J Bacteriol 174, 5302-5308.

Lovitt, R. W., Shen, G. J. \& Zeikus, J. G. (1988). Ethanol production by thermophilic bacteria: biochemical basis for ethanol and hydrogen tolerance in Clostridium thermohydrosulfuricum. $J$ Bacteriol 170, 2809-2815.

McPhedran, P., Sommer, B. \& Lin, E. C. C. (1961). Control of ethanol dehydrogenase levels in Aerobacter aerogenes. J Bacteriol 81, 852-857.

Ogbe Solomon, B., Zeng, A. P., Biebl, H., Okechukwu Ejiofor, A., Posten, C. \& Deckwer, W. D. (1994). Effects of substrate limitation on product distribution and $\mathrm{H}_{2} / \mathrm{CO}_{2}$ ratio in Klebsiella pneumoniae during anaerobic fermentation of glycerol. Appl Microbiol Biotechnol 42, 222-226.

Padan, E., Zilberstein, D. \& Schuldiner, S. (1981). pH homeostasis in bacteria. Biochim Biophys Acta 650, 151-166.

Petitdemange, G., Dür, C., Abbad Andaloussi, S. \& Raval, G. (1995). Fermentation of raw glycerol to 1,3-propanediol by new strains of Clostridium butyricum. J Ind Microbiol 15, 498-502.

Ruch, F. E., Lengeler, J. \& Lin, E. C. C. (1974). Regulation of glycerol catabolism in Klebsiella aerogenes. J Bacteriol 119, 50-56.

Saint Amans, S. (1994). Etude physiologique de la production de 1,3-propanediol chez Clostridium butyricum. PhD thesis, INSA, Toulouse, France.

Sawers, G. \& Böck, A. (1988). Anaerobic regulation of pyruvate formate-lyase from Escherichia coli K-12. J Bacteriol 170, 5330-5336.

Snoep, J. L., Teixeira de Mattos, M. J., Postma, P. W. \& Neijssel, O. M. (1990). Involvement of pyruvate dehydrogenase in product formation in pyruvate-limited anaerobic chemostat cultures of Enterococcus faecalis NCTC 775. Arch Microbiol 154, 50-55.

Streekstra, H., Teixeira de Mattos, M. J., Neijssel, O. M. \& Tempest, D. W. (1987). Overflow metabolism during anaerobic growth of Klebsiella aerogenes NCTC 418 on glycerol and dihydroxyacetone in chemostat culture. Arch Microbiol 147, 268-275.

Takahashi, S., Abbe, K. \& Yamada, T. (1982). Purification of pyruvate formate-lyase from Streptococcus mutans and its regulatory properties. J Bacteriol 149, 1034-1040.

Tarmy, E. M. \& Kaplan, N. O. (1968). Kinetics of Escherichia coli B D-lactate dehydrogenase and evidence for pyruvate-controlled change in conformation. J Biol Chem 243, 2587-2596.

Toraya, T., Ushio, K., Fukui, S. \& Hogenkamp, H. P. C. (1977). 
Studies on the mechanism of the adenosylcobalamin-dependent diol dehydrase reaction by the use of analogs of the coenzyme. J Biol Chem 252, 963-970.

Vasconcelos, I., Girbal, L. \& Soucaille, P. (1994). Regulation of carbon and electron flow in Clostridium acetobutylicum grown in chemostat culture at neutral $\mathrm{pH}$ on mixture of glucose and glycerol. J Bacteriol 176, 1443-1450.

Witt, U., Muller, R. J., Augusta, J., Widdecke, H. \& Deckwer, W. D. (1994). Synthesis, properties and biodegradability of polyesters based on 1,3-propanediol. Macromol Chem Phys 195, 793-802.
Zeng, A. P. (1995). Effect of $\mathrm{CO}_{2}$ absorption on the measurement of $\mathrm{CO}_{2}$ evolution rate in aerobic and anaerobic continuous culture. Appl Microbiol Biotechnol 42, 688-691.

Zeng, A. P., Biebl, H., Schlieker, H. \& Deckwer, W. D. (1993). Pathway analysis of glycerol fermentation by Klebsiella pneumoniae: regulation of reducing equivalent balance and product formation. Enzyme Microb Technol 15, 770-779.

Received 9 September 1996; revised 26 February 1997; accepted 1 March 1997. 